\title{
Patterns of expression of cell wall related genes in sugarcane
}

\author{
D.U. Lima, H.P. Santos, M.A. Tiné, F.R.D. Molle and M.S. Buckeridge*
}

\begin{abstract}
Our search for genes related to cell wall metabolism in the sugarcane expressed sequence tag (SUCEST) database (http://sucest.lbi.dcc.unicamp.br) resulted in 3,283 reads (1\% of the total reads) which were grouped into 459 clusters (potential genes) with an average of 7.1 reads per cluster. To more clearly display our correlation coefficients, we constructed surface maps which we used to investigate the relationship between cell wall genes and the sugarcane tissues libraries from which they came. The only significant correlations that we found between cell wall genes and/or their expression within particular libraries were neutral or synergetic. Genes related to cellulose biosynthesis were from the CesA family, and were found to be the most abundant cell wall related genes in the SUCEST database. We found that the highest number of CesA reads came from the root and stem libraries. The genes with the greatest number of reads were those involved in cell wall hydrolases (e.g. $\beta$-1,3-glucanases, xyloglucan endo- $\beta$-transglycosylase, $\beta$-glucosidase and endo- $\beta$-mannanase). Correlation analyses by surface mapping revealed that the expression of genes related to biosynthesis seems to be associated with the hydrolysis of hemicelluloses, pectin hydrolases being mainly associated with xyloglucan hydrolases. The patterns of cell wall related gene expression in sugarcane based on the number of reads per cluster reflected quite well the expected physiological characteristics of the tissues. This is the first work to provide a general view on plant cell wall metabolism through the expression of related genes in almost all the tissues of a plant at the same time. For example, developing flowers behaved similarly to both meristematic tissues and leaf-root transition zone tissues. Besides providing a basis for future research on the mechanisms of plant development which involve the cell wall, our findings will provide valuable tools for plant engineering in the near future.
\end{abstract}

\section{INTRODUCTION}

The plant cell wall is a composite of interwoven polymers that surround plant cells. Among these polymers, polysaccharides are the majority, these being usually grouped into three classes: cellulose, hemicelluloses and pectins. Usually, polysaccharides make $80-90 \%$ of the wall, the other components being proteins and phenolic compounds such as lignin. Cell wall proteins are either of the structural type (glycine and proline rich proteins) or enzymes (Carpita and Gibeaut, 1993).

The cell wall forms the extracellular matrix of plant tissues and on the basis of what is presently known it can be considered rather as another cell compartment in which several metabolic reactions take place (see Plant Physiology and Biochemistry v. 38 for an extensive review).

Among the main functions of the wall are control of growth, cell signaling, defense, selective porosity and carbon storage. As these functions are usually performed simultaneously, the wall has to be both flexible and tough which requires exact/fine metabolic control. As carbohydrates are the principal components of the plant cell wall, understanding the chemical changes that take place in different tissues at different stages of growth and development is the key to understanding how physiological processes are controlled inside the plant.
On the basis of the discovery that structurally different polymers can perform analogous functions in the walls of plants of different taxonomic groups, Carpita and Gibeaut (1993) proposed the separation of plant cell walls into two groups. The group I type of cell wall is typical of dicotyledonous plants (and some monocotyledonous plants) having xyloglucan (one of the major hemicelluloses in higher plants) as the principal hemicellulose and a higher proportion of pectins. The group II type cell wall is characteristic of monocotyledonous grasses (the Poaceae or Gramineae) and although xyloglucan is still present the dominant hemicelluloses are usually arabinoxylans and $(1,3)-(1,4)-\beta$-glucan (also known as mixed linkage glucan or $\beta$-glucan) and these walls have a lower proportion of pectins.

The biochemical changes that take place in cell walls are performed mostly by enzymes, principally hydrolases which are of two types, endo- and exo-enzymes (Table I). Endo enzymes attack polymers anywhere in the main chain, producing polymer fragments of low molecular weight while the exo-hydrolases can only attack a polymer by breaking the glycosidic linkage in the non-reducing end. Another family of enzymes which are important in the plant cell wall are the xyloglucan endotransglycosylases (XETs). Besides hydrolyzing xyloglucans, these enzymes are also capable of transferring fragments of xyloglucan 
inter-molecularly, a phenomenon has been exhaustively studied since about 1991, and it is presently believed that XETs are equally important in the biosynthesis and degradation of xyloglucans (Campbell and Braam, 1999).

Except for cellulose and callose, which are synthesized at the membrane level, the enzymes related to cell wall polysaccharide biosynthesis can not be strictly considered as cell wall enzymes, since they are active mainly in the cytoplasm on the membranes of the Golgi apparatus. Nevertheless, it is obvious that these enzymes have a direct impact on the events taking place in the cell wall and therefore for the purpose of this paper they will be considered as being cell wall enzymes.

The plant cell wall is thought to be composed of three independent domains; cellulose-hemicellulose (the microfibril and the microfibril orientating domain) pectin (control of porosity and a source of cell signaling for defense) and protein (cross linking and wall loosening). Clearly all three domains are involved in the maintenance of the mechanical properties of the wall. Thus, the three of the most relevant features in the control of cell wall function in plants are the topology and specificity of the cell wall related enzymes and the exact timing by which they are present at the cell wall at the correct stage of development.

All the information necessary for topology, specificity and timing to combine and form a pattern of polymers in the wall of a given plant tissue are 'written' in the genes that encode the enzymes and other proteins that participate in the process of their production, transport, secretion and action. Therefore, studying gene expression can be very useful to understand how these patterns are formed, maintained and degraded.

Group II cell walls are of special interest to us because our subject of interest was sugarcane. The composition and chemical structure of the cell walls of sugarcane has not yet been directly studied. However, a few papers have been published that take into account the cell wall polysaccharides in sugarcane, these papers normally concentrating on the properties of sugarcane sap/juice, the cell wall polymers usually being called indigenous polysaccharides (IPs) (Roberts et al., 1976). The analytic work performed on the composition of IPs clearly indicate that sugarcane has the typical polymers of the group II cell walls.

We studied the expression of cell wall related genes present in the sugarcane expressed sequence tag (SUCEST) database (http://sucest.lbi.dcc.unicamp.br) using digital northern blots constructed by computer analysis of the reads found in the different libraries of the database. Digital northern analysis provided us with an idea of which cell wall proteins were expressed (and at what intensity they were expressed) in different sugarcane tissues. We also constructed correlation surface maps which made possible a general appreciation of the pattern of expression of cell wall related proteins in the entire plant.

\section{MATERIAL AND METHODS}

\section{Search of cell wall related proteins}

The clusters related to cell wall proteins were obtained from the SUCEST database by searching with keywords and the basic local alignment search tool (BLAST) using well known cell wall genes. The keywords used were: arabinosidase, cellulase, cellulose synthase, endopolygalacturonase, expansin, extensin, fucosyltransferase, galactanase, alfa galactosidase, beta galactosidase, alfa galactosyltransferase, beta glucanase, beta glucosidase, laccase, lichenase, beta mannanase, beta mannosidase, pectin acetylesterase pectin methylesterase, pectinesterase, peroxidase, polygalacturonase, xylanase, xyloglucan endotransglycosylase and xylosidase. Keywords that did not show any homology with clusters in the sugarcane database were cellobiohydrolase, galacturonyltransferase, glucoronidase, glycine rich protein, hydroxyproline rich protein, mannosyltransferase, rhamnogalacturonase and xylosyltransferase. The lists of matches (from the NCBI database) related to each cluster, were checked for authenticity as a potential cell wall related gene firstly by association with a plant

Table I - Some features of the principal plant cell wall polysaccharides and the enzymes involved in their degradation.

\begin{tabular}{llll}
\hline Polysaccharide & Main chain residue & Branching residues & Enzymes \\
\hline Mannans & Mannose & Generally none, rarely galactose & Endo- $\beta$-mannanase \\
Glucomannan & Mannose, Glucose & Galactose & Endo- $\beta$-mannanase, Endo- $\beta$-glucanase, $\alpha$-galactosidase \\
Galactomannans & Mannose & Galactose & Endo- $\beta$-mannanase, $\alpha$-galactosidase, exo- $\beta$-mannanase \\
Xyloglucans & Glucose & $\begin{array}{l}\text { Xylose, galactose, } \\
\text { fucose, arabinose }\end{array}$ & $\begin{array}{l}\text { Xyloglucan-endo- } \beta \text {-transglycosilase, } \text { Xyloglucan-endo- } \beta \text {-glucanase, } \\
\beta \text {-galactosidase, } \alpha \text {-xylosidase, } \beta \text {-glucosidase, } \alpha \text {-fucosidase }\end{array}$ \\
Galactans & Galactose & Arabinose & Exo-galactanase, $\alpha$-arabinosidase \\
Arabinoxylans & Xylose & Arabinose, Glucuronic acid & $\beta$-xylosidase, endo- $\beta$-xylanase, $\alpha$-arabinosidase, $\alpha$-glucuronidase \\
$\beta$-Glucan & Glucose & None & Lichenase, $\beta$ - $(1,3)(1,4)$-glucosidase \\
Callose & Glucose & None & $\beta$-(1,3)-glucanase \\
Cellulose & Glucose & None & Cellulase, $[$ endo $\beta$ - $(1,4)$-glucanase] \\
\hline
\end{tabular}


gene, secondly by checking for any existing relevant bibliography and thirdly by limiting the e-value to a maximum of $1 \mathrm{e}-50$. Subsequently, the reads within the clusters were grouped by protein and library.

The libraries investigated were: AM1 = apical meristem (young leaves and stem of mature plants), AM2 = apical meristem (young leaves and stem of immature plants), CL3, CL4 and CL6 = callus tissue submitted to a 12 hour: 12 hour light/dark regime and temperature $\left(4^{\circ}\right.$ and $37^{\circ} \mathrm{C}$ ) stress, FL1 $=1 \mathrm{~cm}$ flowers, FL2 $=20 \mathrm{~cm}$ flowers with size, FL3 $=5 \mathrm{~cm}$ long flower stem, FL $4=50 \mathrm{~cm}$ long flowers stem, FL8 $=10 \mathrm{~cm}$ long flower stem, LB1 and LB2 $=$ Lateral buds; LR1 and LR2 $=$ leaf roll, LV1 $=$ etiolated leaves from plantlets, RT1 and RT2 = roots from young plants, RT3 = roots from adult plants, RZ1, RZ2 and RZ3Leaf-root transition zone, SB1 = Stem bark, SD1 and SD2 = seeds in different stages of development, ST1 = Stem (first internode) and ST3 = Stem (fourth internode).

The data were normalized in order to compare the different libraries and proteins. The number of reads obtained for every cell wall related gene found in each library was divided by the total number of reads of the respective SUCEST library. Because some values were quite low, we expressed them as the number of reads per 10,000 library reads. To construct the surface maps, the reads were grouped according to the libraries from which they were obtained, e.g. all the root libraries (RT1+RT2+RT3) were grouped together as roots and so forth. The reads from library tests ( 500 reads) were discarded.

\section{Statistical analysis}

In order to understand the degree of association in expression (number of reads) for different cell wall proteins, simple linear correlation analysis (r) was used. Using this approach we were able to observe the direction (synergism or antagonism) and the magnitude of each association between two cell wall genes (independently of the library from which they originally came), or between two libraries (independently of the cell wall related gene). The values obtained ranged from -1 to 1: where 'zero' means that the variables do not vary together at all, 'positive' means that the two variables tend to increase or decrease together (synergism), and 'negative' means that the variables are inversely related (antagonism) (Motulsky, 1995).

The correlation analyses were made using the 'Tool Analysis' function of the Excel program (Microsoft Corporation, USA), and the calculated coefficients were statistically tested using the 'r Table' of Snedecor (1946) which follows a distribution with $\eta-2$ degrees of freedom $(\eta=$ number of pairs) at the $5 \%$ probability level. To view the topographical patterns, the correlation coefficients for libraries or genes were plotted as surface graphs using the graph tools available in the software. The ' $r$ ' value was considered as a dependent variable, and only significant statistical coefficients were included.

\section{RESULTS AND DISCUSSION}

The search for genes related to cell wall metabolism resulted in 459 potential genes (clusters) which corresponded to 3,283 reads ( 7 reads per cluster). The average number of cell wall related reads per library was about $1 \%$ of the total number of reads in the database (Figure 1). About $50 \%$ of the total number of cell wall related reads occurred in the following tissue libraries: RT1+RT2 (roots from young plants), RT3 (roots from adult plants), SB1 (stem bark), FL4 (flower stem), ST1 (first internode), ST3 (fourth internode), RZ3 (leaf-root transition zone) and AM2 (apical meristem from young plants) (Figure 1A).

Cellulose synthase, peroxidase, expansin, $\beta$-glucosidases $\beta-1,3$ glucanases were among the more highly expressed cell wall genes in sugarcane (Figure 1B). However, the high standard deviation found for each gene suggest
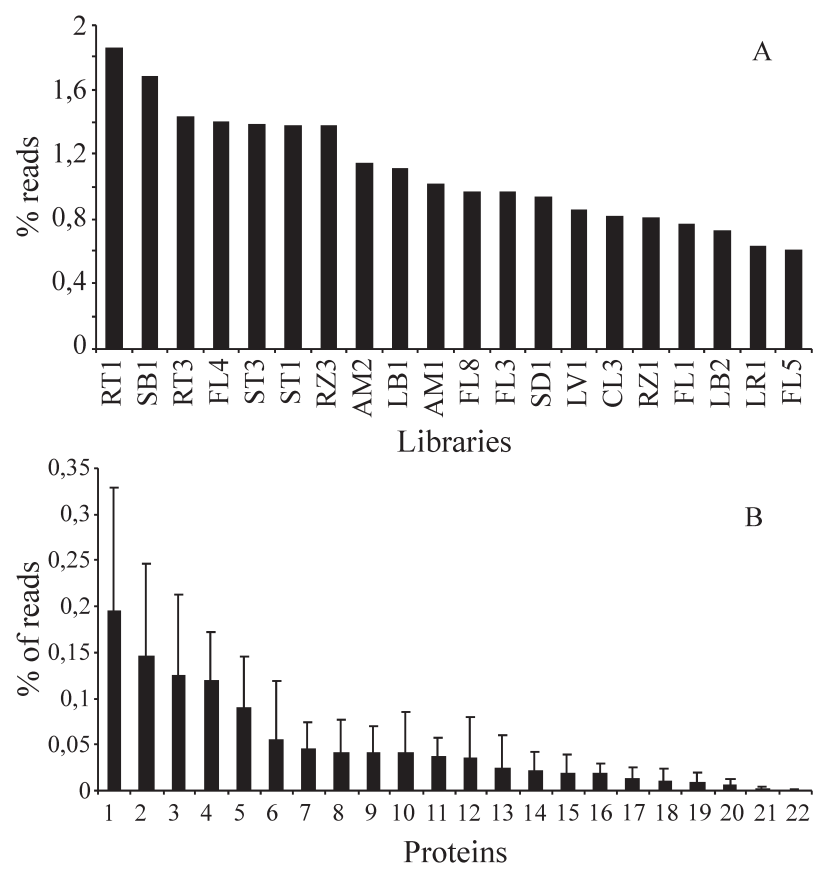

Figure 1 - Expression of cell wall related genes shown as percentage of the number of reads. (A) Number of cell wall related reads in relation to the total number of reads in each library. The AD1 (1.2\%) and HR1 (1.0) libraries were accounted for but are not shown. (B) Total number of reads from a related cell wall gene in relation to the total reads in the sugarcane expressed sequence tag (SUCEST) database. The nomenclature used for libraries in (A) were the same used in the SUCEST project : AMs = apical meristem, CLs $=$ callus, FLs $=$ flower/stem flower, $\mathrm{LBs}=$ lateral buds, $\mathrm{LV}$ $=$ etiolated leaves, $\mathrm{RTs}=$ roots, $\mathrm{RZs}=$ leaf-root transition zone, $\mathrm{SB}=$ stem bark, SDs $=$ seeds, STs $=$ stems. Libraries from equivalent tissues were placed together, e.g. CL3+CL4+CL6, RT1+RT2, RZ1+RZ2, SD1+SD2. In (B) the proteins are represented by numbers: $1=$ cellulose synthase; $2=$ peroxidase; $3=$ expansin, $4=\beta$-glucosidase, $5=\beta$ - $(1,3)$ glucanase, $6=$ XET, 7 = Endopolygalacturonase; $8=$ Pectin(acetyl)(methyl)esterase; 9 $=$ Galactanases; $10=$ Lichenase; $11=$ Cellulase; $12=$ Mannanase $/$ mannosidase; $13=$ Laccase; $14=\alpha$-galactosidase $; 15=\beta-1,4$ xylosidase; $16=$ $\beta$-galactosidase; $17=$ Extensin; $18=\alpha$-galactosyl transferase; $19=\alpha$-arabinosidase; $20=\alpha$-xylosidase; $21=$ xylanase and $22=\alpha-(1,2)$ fucosyltransferase. The bars shown in figure (B) represent the standard deviation among the libraries. 
that expression can be highly dependent on the tissue (library) investigated.

This survey, containing the frequency distribution of reads (per 10,000 reads) of each cell wall related gene per library, generated a highly complex pattern of cell wall gene expression and in order to better visualize the tendencies, surface maps were constructed (Figures 2, 3 and 4).

The proportion of reads in each library varied greatly and the pattern of expression (Figure 2) revealed that cellulose synthase is highly expressed in root and stem tissue as well as in tissues from the transition zone. Some other genes appeared to be expressed simultaneously in these libraries such as $\beta$-glucosidase, $\beta$-1,3-glucanase (callose), pectin esterase and peroxidase (phenolic compounds). XET and mannanase were expressed in stems but not in roots (Figure 2).

Pectins presented a differential pattern of expression with pectin esterase present in stem and roots, endo-polygalacturonase mainly in leaves and galactanase mainly in flowers (Figure 2). Mannans seem to have been associated almost exclusively with stems, since a higher number of reads was found in normal stem and flower stem.

The CesA gene family, related to cellulose biosynthesis (Holland et al. 2000), deserves a special mention. It is by far the largest cell wall related gene family found in sugarcane. Before this study we had already found 18 different $\operatorname{Ces} A$ clusters (genes) and their distribution within the cane as well as comparisons with the CesA families from maize, Arabidopsis, rice and cotton will be published elsewhere. Since the studies on polysaccharide synthases are not as developed as for hydrolases, this high number of reads should be viewed with some caution because other glycosyltransferases (such as other $\beta$-glucan, xylan and mannan synthases) may have been included among the CesA genes, artificially increasing the number of reads of this gene found in the libraries.

Peroxidase is an important cell wall enzyme thought to be related to wall tightening (Boudet, 2000) and genes for this enzyme were found at a high frequency in root and stem tissues, including flower-stem tissues (Figure 2). This pattern of expression is consistent with tissues where the formation of vascular bundles is more intense.

\section{Correlation between genes that encode the action of enzymes in the cell wall}

One of the most important events during development is the orientation of cellulose microfibrils in the cell wall (McCann and Roberts, 1991; Talbott and Ray, 1992; Carpita and Gibeaut, 1993) and two steps, division and extension, are thought to be key phases in wall development. During cell division, the formation of the phragmoplast (the equatorial region of the spindle during anaphase from which the cell plate develops at telophase from which it is believed the middle lamella is formed) involves the bio-

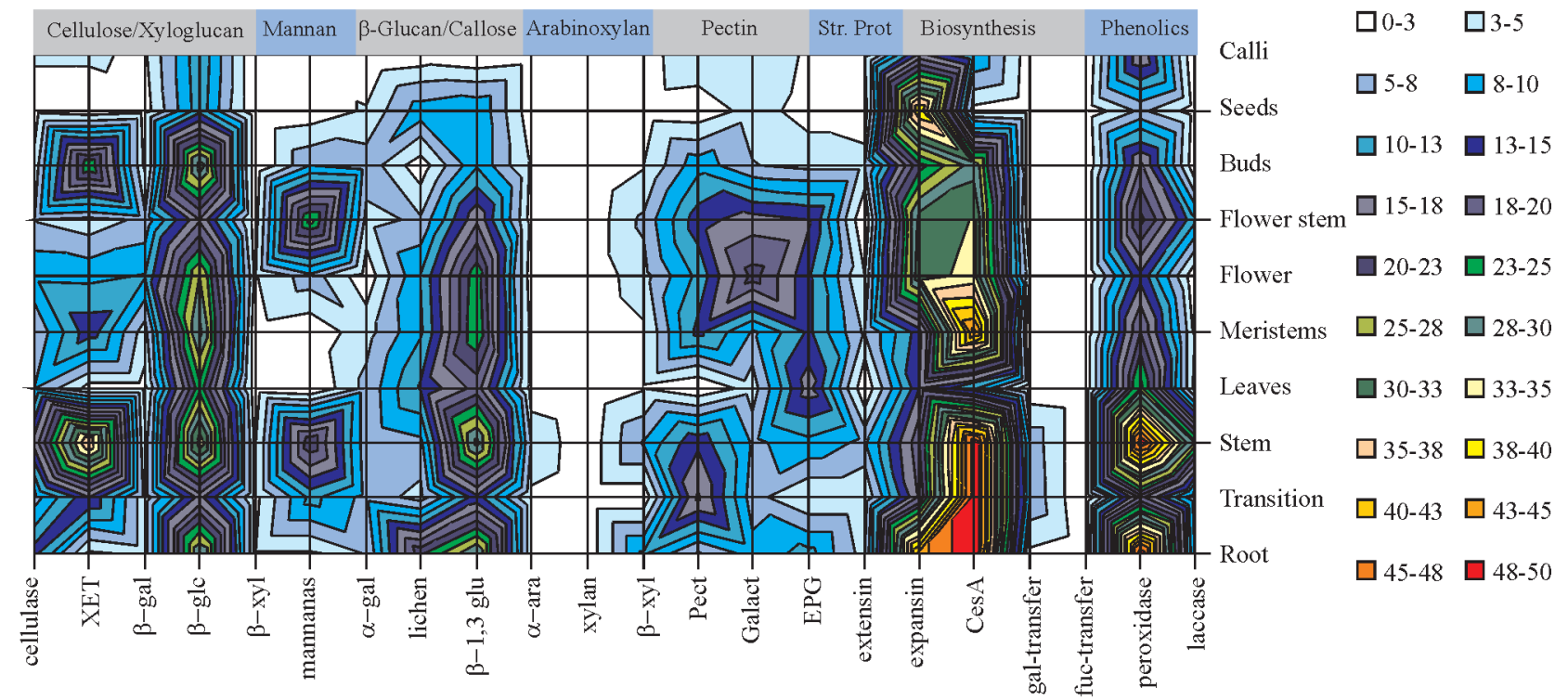

Figure 2 - Surface map of the frequency of reads for cell wall genes according to their library of origin. The cell wall polymers are grouped at the top according to the genes (enzymes) related to them which are shown at the bottom. The total number of reads (obtained for each gene searched by a basic local alignment search tool (BLAST) search using keywords or known genes) were normalized. The libraries were grouped as follows: CALLUS $=$ CL3, SEEDS $=$ SD1+SD2, BUDS $=$ LB1+LB2, FLOWER STEM $=$ FL4+FL8, FLOWER $=$ FL1+FL3+FL5, MERISTEMS $=$ AM1+AM2, LEAVES $=$ $\mathrm{LR} 1+\mathrm{LR} 2+\mathrm{LV} 1, \mathrm{STEM}=\mathrm{ST} 1+\mathrm{ST} 3+\mathrm{SB} 1$, TRANSITION $=\mathrm{RZ1+RZ2+RZ3,} \mathrm{ROOT}=\mathrm{RT} 1+\mathrm{RT} 2+\mathrm{RT} 3$. The genes were grouped as follows: Cellulose and $x y \operatorname{loglucan}=$ cellulase $($ endo- $\beta$-glucanse), XET (xyloglucan endo- $\beta$-transglycosilase), B-gal ( $\beta$-galactosidase, B-glc ( $\beta$-glucosidase); Mannan = mannanas (endo- $\beta$-mannanase); a-gal ( $\alpha$-galactosidase); $\beta$-glucan/callose $=$ lichen (lychenase), B-1,3 glc $(\beta$-1,3-glucanase); Arabinoxylan $=$ A-ara $(\alpha$-arabinosidase), endo-xylan (endo- $\beta$-xylanase), B-xyl ( $\beta$-xylosidase; Pectin $=$ Pectin-esterase (pectin acetylesterase+pectin methyesterase+pectin esterase), Galactanase ( $\beta$-galactosidase+galactanase), EPG (endo polygalacturonase); Proteins = extensin and expansin; Synthesis $=$ CesA $($ cellulose synthase), gal-transfer ( $\alpha$-galactosyltransferase), fuc-transfer (a-1,2-fucosyltransferase); Phenolics $=$ peroxidase and laccase. 


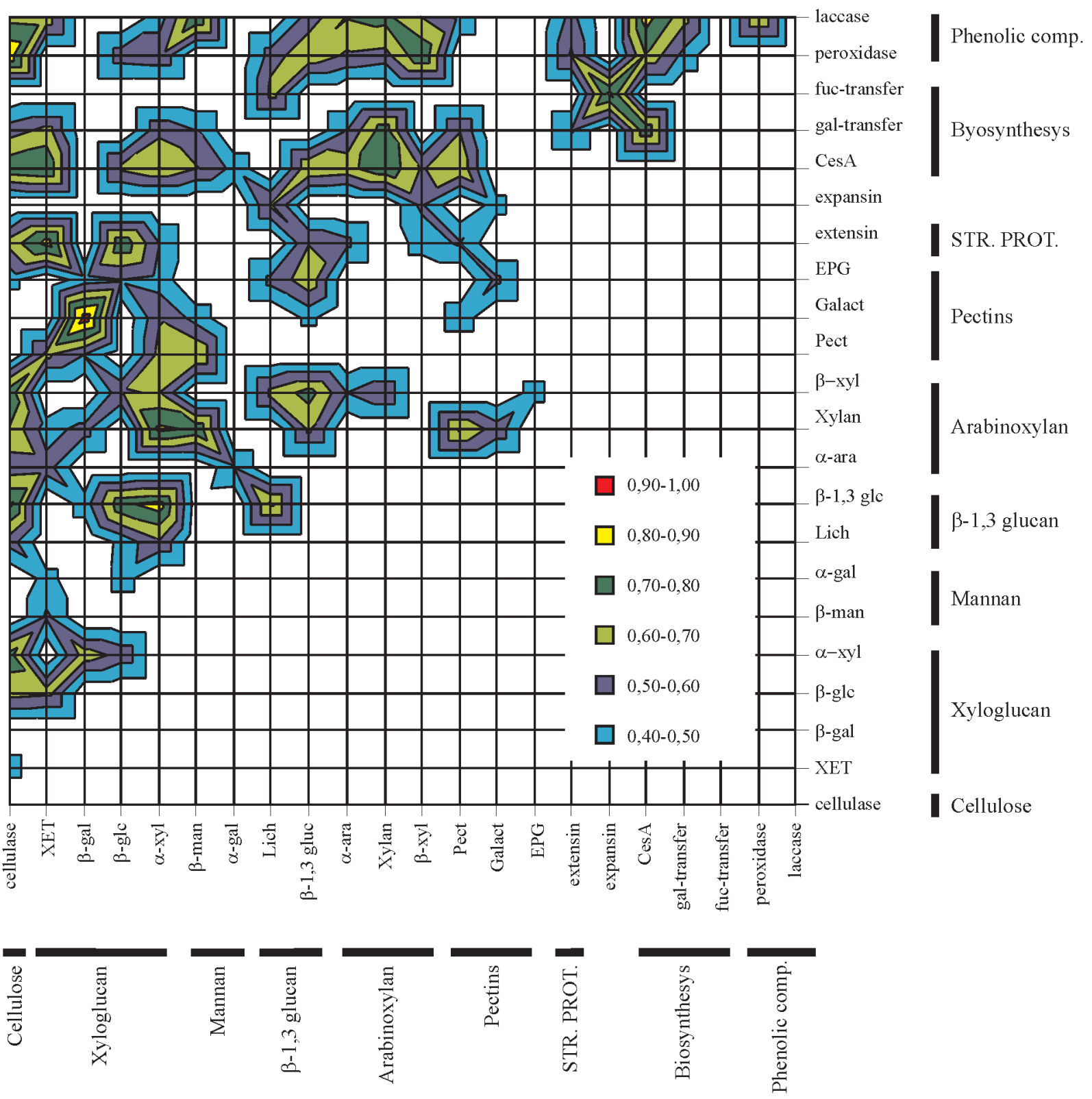

Figure 3 - Correlation between sugarcane cell wall related genes. Calculations were performed with the number of reads obtained for each gene by a basic local alignment search tool (BLAST) search using keywords and the amino acid sequences of genes known to be related to cell wall metabolism. The correlation analyses were made using the 'Tool Analysis' function contained in the Excel ${ }^{\circledR}$ software package (Microsoft Corporation ${ }^{\circledR}$, USA), and the calculated coefficients were statistically tested using the 'r Table' of Snedecor (1946) based on a distribution with $\eta-2$ degrees of freedom ( $\eta=$ number of pairs $)$ at the $5 \%$ probability level. $(\mathrm{r}=0.423) \mathrm{XET}=\mathrm{xyloglucan}$ endo- $\beta$-transglycosylase; $\beta$-gal $=\beta$-galactosidase; $\beta$-glc $=\beta$-glucosidase; $\alpha$-xyl $=$ $\alpha$-xylosidase; $\beta$-man $=\beta$-mannanase; $\alpha$-gal $=\alpha$-galactosidase; Lich $=$ lichenase; $\beta$-1,3 glc $=\beta$-1,3-glucanase; $\alpha$-ara $=\alpha$-arabinosidase; Xylan $=$ endo- $\beta$-xylanase; $\beta$-xyl = $\beta$-xylosidase; $P$ Pect $=$ pectinesterases; Galact $=$ exo- $\beta$-galactanase $; \mathrm{EPG}=$ endo-polygalacturonase; CesA $=$ cellulose synthase; gal-transfer $=\alpha$-galactosyltransferase; fuc-transfer $=\alpha$-fucosyltransferase; STR.PROT. $=$ structural proteins .

synthesis of cellulose and the assembly of cellulose molecules into microfibrils simultaneously with the orientation of these microfibrils by hemicelluloses synthesized in the Golgi apparatus at practically the same time. On the other hand, the formation of the phragmoplast has also to involve polysaccharide hydrolysis, since the newly synthesized wall has to fuse with an existent one. After division, plant cells continue to grow by extension and this process also in- volves microfibril orientation since important changes in the mechanical properties of the wall have to be performed in order to allow elongation in a specific direction (Cosgrove, 2000; Whitney et al., 1995). In order to stop growth, cross links between polymers can be made and this is thought to be performed by phenolic compounds and structural proteins such as extensin (Fry, 1988). 


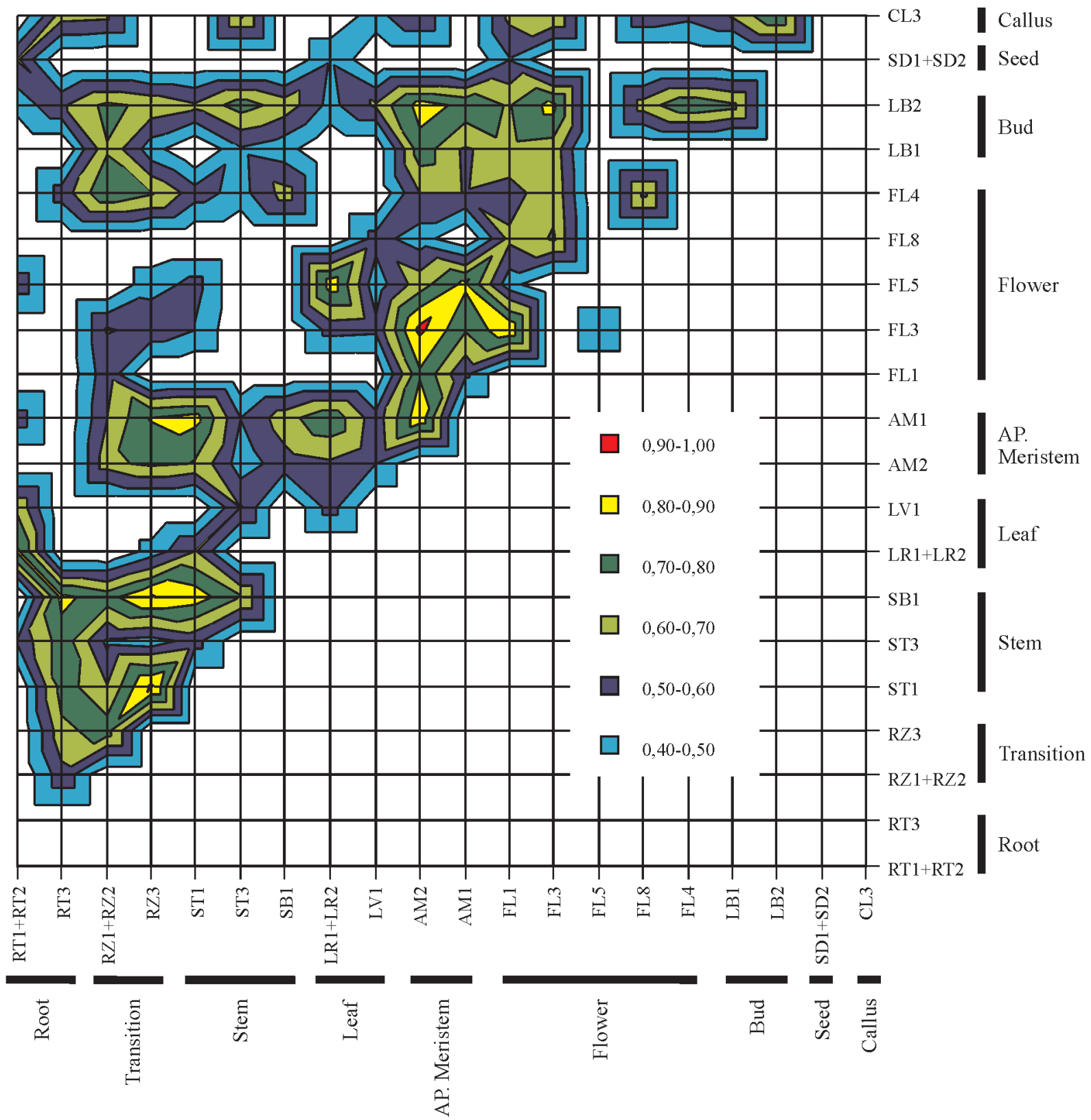

Figure 4 - Correlation between sugarcane cell wall libraries. Calculations were performed with the number of reads obtained for each gene by a basic local alignment search tool (BLAST) search using keywords and the amino acid sequences of genes known to be related to cell wall metabolism. The correlation analyses were made using the 'Tool Analysis' function contained in the Excel ${ }^{\circledR}$ software package (Microsoft Corporation ${ }^{\circledR}$, USA), and the calculated coefficients were statistically tested using the ' $r$ Table' of Snedecor (1946) based on a distribution with $\eta-2$ degrees of freedom ( $\eta=$ number of pairs $)$ at the $5 \%$ probability level. $(\mathrm{r}=0.444)$. AM1- Apical meristem, young leaves and stem of mature plants; AM2- Apical meristem, young leaves and stem of immature plants; CL3- calli submitted to light/dark and $\left(4^{\circ}\right.$ and $\left.37^{\circ} \mathrm{C}\right)$ stress; FL1- Flowers with $1 \mathrm{~cm}$ size; FL3- Flowers with $5 \mathrm{~cm}$ length; FL4Flowers with $50 \mathrm{~cm}$ length; FL8- Flower stem with $10 \mathrm{~cm}$ length; LB1 and LB2- Lateral bud; LR1 and LR2- Leaf roll; LV1- Etiolated leaves from plantlets; RT1, RT2 and RT3- roots; RZ1, RZ2 and RZ3- Leaf-root transition; SB1- Stem bark; SD1, SD2- Seeds in different stages of development; ST1Stem (first internode) and ST3- Stem (fourth internode).

Figure 3 shows the correlation between the groups of genes that work either to hydrolyze or synthesize a given sugarcane cell wall polymer. As only significant correlation coefficients are shown, one outstanding feature of this map is that there is no significant antagonic expression between the groups of cell wall genes analyzed, indicating that 'biochemical operations' on cell wall polymers can be either synergetic or neutral, but never antagonistic. The highest correlation found was between genes that encode xyloglucan and pectin hydrolases. A reasonable explanation for this observation is clearly related to the functions of xyloglucan and pectin in the cell wall, because whereas pectins control wall porosity, xyloglucan is thought to be the principal component involved in the orientation of cel- 
lulose microfibrils (McCann and Roberts, 1991, Carpita and Gibeaut, 1993). The correlation we observed probably means that any modification in microfibril orientation has to have a concomitant change in the size of pores in the wall so that the xyloglucan-degrading enzymes can reach their substrate.

Another situation where there was a strong correlation of gene expression was between the genes that encode xyloglucan and callose/ $\beta$-glucan exo-hydrolases. As proposed for xyloglucan, $\beta$-glucan is thought to be related to microfibril orientation, although this proposition is based solely on the fact that $\beta$-glucan binds specifically to cellulose (Mishima et al., 1998). Another relevant feature regarding $\beta$-glucans is that, in grasses, their appearance is thought to be transitory and related to wall development (Mishima et al., 1998). If these two polymers are really related to microfibril orientation (an important event in wall development) we should indeed expect correlation between genes coding for enzymes involved with these polymers.

Another striking set of correlations was between hemicellulose hydrolysis (cellulases, xyloglucanases, $\beta$-glucanases and arabinoxylanases) and cellulose biosynthesis. There are two ways to explain this correlation. One is through cell wall turnover, during which both hydrolysis and synthesis occur simultaneously and with approximately the same intensity (Gorshkova et al., 1997). Another, non-exclusive, possibility is that the correlation between hydrolytic and synthetic events is reflecting other developmental processes occurring at the same time. This possibility is quite plausible in sugarcane because this plant has a very high rate of growth. Figure 3 shows that lignin hydrolysis (laccase genes) and biosynthesis (peroxidase genes) correlate with almost exactly the same pattern, and this supports the hypothesis that some genes are linked to hydrolysis/biosynthetic events. The situation is still unclear, however, since Boudet (2000) has suggested that laccase also has some role in lignification.

\section{Expression of cell wall related genes in different sugarcane tissues}

Another instructive way to look at the expression of cell wall related genes in sugarcane is to construct surface correlation maps of the libraries which show more clearly the relationships between genes.

For the groups of cell wall genes, only positive correlation coefficients were found (Figure 3), but in Figure 4 the absence of correlation can be used as a measure of the uniqueness of certain libraries. For example, the seed libraries correlated weakly with only a few other libraries, related to root, young flowers and leaf tissues.

The flower libraries are also very interesting in that we detected a high correlation (0.6) between some flower libraries (FL1, FL3 and FL5) and leaf and apical meristem libraries. It is interesting to note that during flower develop- ment the flower libraries tended to reduce their association with apical meristem (AM) libraries and increase their association with leaf roll (LR) libraries. Libraries obtained from the leaf-root transition zone (RZ) and the first internode of stems (ST1) showed a lower, but still significant, correlation with developing flowers. This is probably related to the fact that the leaf-root transition zone correlated highly with apical meristem. Indeed, leaf-root transition zone is typical of a region with high meristematic activity. However, it is important to note that the cDNA from which the apical meristem libraries were constructed was in fact prepared from a mixture containing some leaf and some stem tissues. On the other hand, flower stem library FL8 presented only a little correlation with the young flower libraries FL1 and FL3 while the $50 \mathrm{~cm}$ flower stem FL4 library presented some correlation with stem and root libraries.

Other important correlations were between the bud and flower, bud and apical meristem, bud and root, and stem and root libraries. Again, this is also to be expected from our knowledge of plant physiology.

Topology, specificity and timing, the three features cited as being the keys to our understanding of enzyme action in the cell wall, could not be directly evaluated using gene expression data (ESTs) but a reasonable picture of the co-ordination of events relevant to the whole sugarcane plant as a whole could be distinguished. The fairly high number of reads which we found for the CesA gene family is not surprising, since cellulose synthesis is probably one of the most important anabolic processes in plants. Holland et al. (2000) reminds us that this is probably the reason why considerable redundancy is found for this gene family.

Most of the correlations that we found in sugarcane were quite 'logical' and fit in well with the classical views of plant anatomy and physiology. To our knowledge this is the first time that this approach has been applied to plant cell walls and it would be interesting to see this technique applied to species such as Arabidopsis thaliana and Zea mays, which are among the most studied genomes to date. We are now starting biochemical studies to confirm our observations, and we hope to combine these studies with correlation studies of Arabidopsis and maize to develop other powerful tools for use in plant bioengineering.

\section{RESUMO}

A busca por genes relacionados ao metabolismo da parede celular no banco de dados SUCEST-FAPESP resultou em 459 potenciais genes ("clusters") que correspondem a 3283 clones ("reads"), o que corresponde a cerca de 1.1\% do número total de clones. Foram construídos mapas de superfície para correlacionar os genes com as bibliotecas dos diferentes tecidos. Foram encontradas correlações positivas ou neutras entre os genes em uma mesma biblioteca. Os genes relacionados à síntese de celulose (família $\operatorname{Ces} A$ ) foram os de maior expressão na planta, embora a maior 
expressão esteja associada à raiz e colmo. Entre as hidrolases, $\beta$-1,3-glucanases, xiloglucano endo- $\beta$-transglicosilase, $\beta$-glucosidase e endo- $\beta$-mananase foram os genes com o maior número de clones. Análise de correlação (por mapas de superfície) revelou que a expressão dos genes relacionados à biossíntese parece estar associada à hidrólise de hemicelulose, enquanto as hidrolases de pectina estão relacionadas principalmente às hidrolases de xiloglucano. $\mathrm{O}$ padrão de expressão de genes relacionados à parede celular, baseado no número de "reads" por "cluster" refletiu bem as características fisiológicas esperadas para cada tecido. Este é o primeiro trabalho que fornece uma visão geral do metabolismo de parede celular através da expressão dos genes em vários tecidos ao mesmo tempo. Por exemplo, inflorescências em desenvolvimento se comportaram de forma semelhante a tecidos meristemáticos e à região de transição folha-raiz. Estes dados servirão tanto para pesquisas em fisiologia e desenvolvimento de cana, como também para o desenvolvimento de processos industriais.

\section{ACKNOWLEDGEMENTS}

Authors acknowledge Dr Marcia Regina Braga for a critical review of the manuscript and FAPESP-SUCEST for financial support (grant number 00/07436-9).

\section{REFERENCES}

Boudet, A.M. (2000). Lignins and lignification: Selected issues. Plant Physiol. Biochem. 38: 81-96

Campbell, P. and Braam, J. (1999). Xyloglucan endotransglycosylases: diversity of genes, enzymes and potential wall-modifying functions. Trends Plant Sci. 9 (4): 361-366.
Carpita, N.C. and Gibeaut, D.M. (1993). Structural models of primary cell walls in flowering plants: consistency of molecular structure with the physical properties of the walls during growth. Plant J. 3: 1-30.

Cosgrove, D.J. (2000). Expansive growth of plant cell walls. Plant Physiol. Biochem. 38: 109-124.

Fry, S.C. (1988). The growing plant cell wall: chemical and metabolic analysis. Longman, Harlow, Essex.

Gorshkova, T.A., Chemikosova, S.B., Lozovaya, V.V. and Carpita, N.C. (1997). Turnover of galactans and other cell wall polysaccharide in developing flax plants. Plant Physiol. 114: 723-729.

Holland, N., Holland, D., Helentjaris, T., Dhugga, K.S., Cazares, B.X. and Delmer, D.P. (2000). A comparative analysis of the plant cellulose synthase (CesA) gene family. Plant Physiol. 123: 1313-1323.

McCann, M.C. and Roberts, K. (1991). Architecture of the primary cell wall. In: The Cytoskeletal Basis of Plant Growth and Form (Lloyd, C.W. ed.). Academic Press, London, pp. 109-129.

Mishima, T. Hisamatsu, M., York, W.S., Teranishi, K. and Yamada, T. (1998). Adhesion of $\beta$-D-glucans to cellulose. Carbohydr. Res. 308: 389-395.

Motulsky, H. (1995). Intuitive Biostatistics. Oxford University Press, New York, 386p.

Roberts, E.J., Godshall, M.A., Carpenter, F.G. and Clarke, M.A. (1976). Composition of soluble indigenous polysaccharide from sugarcane. Int. Sugar J. 78: 163-165.

Snedecor, G.W. (1946). Statistical Methods. The Iowa State College Press,USA, 4 ed.

Talbott, L.D. and Ray, P.M. (1992). Molecular size and separability features of pea cell wall polysaccharides. Implications for primary wall structure. Plant Physiol. 98: 357-368.

Whitney, S.E.C., Brigham, J.E., Darke, A.H., Reid, J.S.G. and Gidley, M.J. (1995). In vitro assembly of cellulose/xyloglucan networks: ultrastructural and molecular aspects. Plant J. 8 (4): 491-504. 